\title{
SWALLOWS AND SWIFTS- BEHAVIOR IN A SMALL GEOGRAPHICAL AREA
}

\author{
Mirza S.S. \\ Zoology Department, G.M. Vedak College of Science, Tala, Raigad. (M.S) \\ Email: drmirzashah@gmail.com
}

\begin{abstract}
:
Raigad District is one of the coastal districts of Maharashtra. There are many small ports on the seashore of the district. A comparative study was undertaken of Swallows and swifts found in Raigad District in the year 2019 from (June to May). In the present study six species were taken into consideration for taxonomic, habitation, nesting behaviour, foraging and breeding are focussed from Raigad District. Four different sites (Alibag, Panvel, Mangaon and Mahad) were selected. From each area two, two places were selected for the present study. Number of Swallows found were more in Mahad due to more bridges, water bodies and more insects available for food as found than other regions and swifts found were more in Mahad because of river and bridges and vast infrastructure and food available where Swifts can live.
\end{abstract}

Key words: - Hirundinidae, Apodidae, Taxonomy, Foraging.

\section{INTRODUCTION:}

Raigad district is also like Thane district, a part of North Konkan. It is spread just adjoining to the district of Mumbai to its east and south-east across the Thane creek. It is spread from the Patalganga river basin in the north to Savitri river in the south. Rivers of Raigad are Gangadhari, Surya, Savitri, Kundlika, Kal, Patalganga, Shrivardhana, Mahad, Poladpur, Tala. According to 2001 census, Raigad District has 15 tehsils having 26 census towns, 11 statutory town and 1919 villages.

The common swift was one of the many species described by the Swedish naturalist Carl Linnaeus in 1758 in the tenth edition of his Systema Naturae. He introduced the binomial name Hirundo apus.( Linnaeus, C. 1758). The current genus Apus was erected by the Italian naturalist Giovanni Antonio Scopoli in 1777 based on autonymy.

The term Swallow is used colloquially in Europe as a synonym for the barn swallow. There are around 90 species of Hirundinidae, divided into 19 genera, with the greatest diversity found in Africa, which is also thought to be where they evolved as hole- nesters. (Angela et. al., 2010). They also occur on a number of oceanic islands. A number of European and North American species are longdistance migrants; by contrast, the West and South African swallows are non-migratory. The Barn Swallow is a common bird known from Andamans, Myanmmar, Malay Peninsula and Indonesia (Ali and Ripley: 1987; Turner, 2004). Available information on the reproductive traits of hirundines that breed in the tropics dshows significant deviation from the typical traits of tropical birds (Hails, 1984; Ali and Ripley: 1987; Turner, 2004).

Animal morphology and behavior are inextricably linked, with particular morphologies permitting particular behaviors, and behavioral innovation producing novel selective pressures on relevant morphologies (Allison at.el.2016). Changes in behavior have long been implicated in initiating changes in morphological traits by affecting how species interact with their environment and by altering selective pressures (Duckworth, 2008; Lapiedra, Sol, Carranza, \& Beaulieu, 2013). All species of swallow primarily forage on the wing although occasionally come to ground to take prey. There are only a few 
documented cases of Australian swallow species foraging while on the ground, and descriptions of foraging techniques in these instances are limited. Here we provide details of observations on ground-foraging of the Welcome Swallow Hirundo neoxena in south-eastern Australia, as well as an instance of kleptoparasitism. (James at.el. 2012).

Hirundines shows significant geographic variations in the timing of breeding. In the subtropics and tropics nesting is limited to the wet season when insects are most abundant or can occur almost throughout the year, sometimes with peaks during rains (turner, 2004).Majority of the species in India breed chiefly during March-July (Ali and ripley, 1987)

Nest building material of birds has been studied by many like Dewar (1909), Ali (1931), Mathew (1972), Davis (1973), Clark \& Mason (1985), Fauth et.al. (1991), Sharma (1991), Brouwer \& Komdeur (2004). Generally, swallows select mud with appropriate proportion of silt and sand to build nest (Kilgore and Knudsen, 1977).

\section{METHOD AND METHODOLOGY:}

In the starting many areas were toured and finally eight areas were selected. The eight given areas were surveyed weekly. Field exploration and survey was undertaken locate habitat of these birds. The investigation was carried out from January to December (2019). As the habitats varied considerably, the avifauna was assessed using both point count and line transect methods (variable width line transect method (Burnham et al 1980)). Birding was done in the early hour's i.e from morning 6.00am to 10.00AM and also in the evening from 05:00 pm to 07:00 PM. Sometimes whole day was spent in observing birds for their foraging behaviour and during nest construction. Birds were sighted using a $10 \times 50$ wide angle Celestron binocular and the birds were photographed using Mobile camera and canon simple camera. Birds were identified with the help of local bird watchers, farmers and wild life professionals and the identification was confirmed by authentic scientific literature on birds (felid books) (Salim Ali's Book, Check List of ZSI and Research Papers). Birds were studied by direct observation. For observation of foraging activities breeding season was taken into consideration as these Swallows and swifts wander more in this period of time.

Various possible nesting sites of Wiretailed swallows located especially under the large and high bridges of tar roads and railway were weekly visited specially in rainy season. One day at each nesting site was spent to observe the nest building process by Swallows and also changing positions. The Indian swiftlet (Collocalia unicolor) were very rare sighted only at Mahad and Murud in natural caves.

Study areas: The sites selected were numbered as:
1) Alibag: a)Pen
b) Murud
2) Panvel:
a)Uran
b) Panvel
3) Mahad:
a) Poladpur
b) Mahad
4) Mangaon:
a) Tala
b) Roha

\section{Objective of the study:}

To Know the biodiversity of Swallows and Swifts and their behaviour related to foraging, nesting, breeding season, taxonomy in Raigad District. The species selected for the study are given below:

Barn swallows (Hirundo rustica), wire tailed swallow Hirundo smithi (Leach, 1818)/ Hirundo filifera (Stephans, 1826) and Little Swift-Apus affinis (J.E.Grey, 1830) and The Indian swiftlet (Collocalia unicolor) Hill Swallow (Hirundo domicola)

\section{Nest construction Process:}

The swallows (Barn and wire-tailed Swallows) carry the nesting material that is wet mud in its 
mouth. They dig suitable mud from coastal areas as well as wet soiled area after rains. By preparing a mud pellet in their beaks and carried out one by one to their nests which is gourd shape. (Diameter about 1.0 to $1.5 \mathrm{~cm}$ ) and about 1500 to 1800 mud pellets were used to construct a single nest taking few hours to few days as both male and females together builds a nest (Brown C R et.al.2000) . It depends upon availability of site, water bodies and bridges for swallows to decide the number of nests to be constructed. Sometimes there are buildings, bridges but no water bodies so the nests are less in numbers. Barn Swallows and Wire tailed Swallow Prepare nests of specific gourd shape having typical blue print design with specific architectural structures (Chayya at.el 2014), Swallows prefer higher elevation from ground to construct their nests near to raw materials required for nest building at safe distance from the reach of enemies like ants, snakes, and predators like crow, hawks, kite and nuisance from human being. The length can be from 6 to 10 inches long and breadth can be from 3 to 5 inches wide.The nests of Hill swallows were cup-shaped (nest diameter: $11.46 \pm 0.76 \mathrm{~cm}$, cup diameter: $8.59 \pm 0.81 \mathrm{~cm}$, outer nest depth: $7.86 \pm 0.76 \mathrm{~cm}$, cup depth: 5.4 $\pm 0.73 \mathrm{~cm}$, nest thickness: $1.42 \pm 0.34 \mathrm{~cm}$ ) made with mud pellets as major structural constituent. The nest of The Indian swiftlet (Collocalia unicolor) builds the nest with its own saliva but now it contains other materials also.

\section{Nesting material:}

The construction material majorly consists of sand, clay, slit, feathers, plastics, twigs, cotton threads, etc. along with their saliva was used in Barn or wire-tailed swallows. But in Cliff Swallows, dried grasses, moss, pteridophyte roots and lichens were also used in the structural layer, mostly in nests placed in tunnel/culvert sites. The amount of these materials was considerably minimal in the nests placed in buildings. (P. BALAKRISHNAN 2010). The Indian swiftlet (Collocalia unicolor) builds the nest with its own saliva which has some gastronomic and commercial value (Ali \& Ripley 1981). In 2001, Mr. J. C. Daniel at.el noticed that the nests were made up with more grass and feathers than saliva. The nests were shaped like a deep oyster shell, 42-45 mm O.D. and 41$43 \mathrm{~mm}$ I.D. in size.

Discussions: In the present studies foraging of is seen in air only of all species but twice foraging is seen in case of Indian Cliff Swallow Hirundo fluvicola Blyth 1885 which support that Welcome swallow was also seen in Australia on ground. (Higgins et al. 2006). Avian foraging strategies combine complex interactions among morphology, prey preference, foraging behaviour, habitat selection, prey availability and relationships with predators and competitors (Morrison et al. 1990). Quantifying these components of a species foraging strategy can explain niche relationship (Robinson \& Holmes, 1982), patterns of habitat use (Karr \& Brawn, 1990), and community structure (MacArthur, 1958) and can also help to focus conservation efforts (Petit et al. 1995). However much of the data necessary to characterize a species foraging strategy, are lacking including dietary information (Rosenberg \& Cooper, 1990).

Swallows represent the most accepted exemplar for behavioral and ecological research (Brown and Brown 1991; Winkler and Sheldon 1993; Turner and Rose 1989). The swallows have an evolutionarily slender, streamlined body with elongated edged wings, which complements immense mobility, pertinacity, and facilitate in recurrent period of gliding adapted for hunting insects while on the wing (Turner 2004). The sexes exhibit partial or no sexual dimorphism, except for longer tail feathers in the adult males (Møller 1992). The family exploits an extensive 
dimension of habitats. The nests and nesting sites vary among different species of swallow. Numerous species have expanded their range of habitation by inhabiting modified human surroundings consisting of agricultural land, bridges, culverts and urban locality (Brown and Brown 1986; Turner 2004). Swallows construct exclusively mud nests, which are attached to the vertical surface. Both the members of each pair contribute to the nest construction (Keith et al. 1992).

The species Swift Alpine Tachymarpitis melba are found in Mahad where Kal-Savitri valley is located in the south of the district. It comprises of parts of Mangaon and Mahad tehsils, and small parts of Mhasla and Poladpur tehsils. The $\mathrm{Kal}$ and Savitri are the main river systems in this region. The Kal River flows south into the Savitri River, which flows westwards. Hill Swallow Hirundo domicola were found in Kundlika or Roha River. Wire-tailed Swallow Hirundo filifera Stephans, 1825 were found near Mandad river, Tala and Mangaon. Common/ Barn Swallow Hirundo rustica were found in Poladpur, Uran. Mahad. House swift Apus affinus were seen at Poladpur, Pen, Panvel and Tala. Swift Alpine Tachymarpitis melba were seen at Mahad only. It dosent mean that these birds are specific to that region. They were also seen at different regions also but as a greater number of birds were present in the described place.

All species found were studied from Raigad Region. In the $2^{\text {nd }}$ table some species were common while the variation of region may be possible in different seasons while comparing with table no. 1st. Variation is seen in morphometrics of present Wire-tailed swallow from Wire-tailed swallow of Chavan at. el. (2014) in size of tail and fins, Present Wire-tailed Swallow is bigger because the habitat is Western
Ghats- Biodiversity hotspot; where food (insects) are available in abundance during and after rainy season. All species morphometrics was not performed. Hirundo smithii nesting period is all the year round. The foraging behavior is seen in House swift Apus affinus affinus from Nov to Feb. In Common/ Barn Swallow Hirundo rustica nesting period from April to July.

Results: From the table. I can conclude that Mahad has most of the nests of swallows and swifts then Murud has, but all the other places have only swallows' nests. For a single nest construction of swallows, it requires about 1800 rounds followed by Panvel nest constructionin Pen. Mahad and Roha, the clutch size is 3-4 eggs and in one-hour swallows visit their homes for security reasons 65 time in one hour in Roha and Panvel but makes less rounds in other places as it does not feel any insecurity. There were more manmade structures than natural because it is convenient for birds. The swifts are less and now using less saliva to construct nests because many poachers as well as predators eat their nest and its nest has high commercial values.

Conclusion: Number of Swallows found were more in Mahad due to more bridges, water bodies and more insects available for food as found than other regions and swifts found were more in Mahad because of river and bridges and vast infrastructure and food available where Swifts can live. The other favourable factor can be climatic conditions. It has been observed that a old used nest of one Cliff Swallow (solitary) was broken partly by another another Cliff Swallow and the remaining new construction takes place (figure 2 and figure 3). The structure of the nest showed variations in length of the entrance tunnel, outer entrance tunnel perimeter, upper attachment length. 


\section{REFERENCES:}

ALI, S. \& S.D. RIPLEY. (1987): Handbook of the birds of India and Pakistan. Compact ed. Oxford University Press, New Delhi.

ALI, S. (1931): The nesting habits of the Baya (Ploceus philippinus). J. Bombay Nat. Hist. Soc. 34: $947-$ 96

Allison at.el.2016:Convergent evolution in social swallows (Aves: Hirundinidae): Ecology and Evolution 2017; 7: 550-560 www.ecolevol.org

Anand at.el (2007): Season and Landscape Element Wise Changes in the community Structure of Avifauna of Tamhini Northern Western Ghats, India. ZOOS` Print Journal 22 (9) :2807-2815. ISSN 0973-2535

Angela Turner; Chris Rose (2010). A Handbook to the Swallows and Martins of the World. A\&C Black. p. 12. ISBN 9781408131725.

Anil Mahabal at. el (2007): Status Survey of Indian Ediblenest Swiftiet Colloealia unieolor (Jerdon) in Western Ghats, West Coast and Islands in Arabian Sea, India, Zoological Survey of India Kolkata (page 5-6)

Arti singh Ph.D thesis (2014): School of Life Sciences, Pt. Ravishankar Shukla University, Raipur 492010, India Page $.1 \& 8$.

BROUWER, L. \& J. KOMDEUR (2004): Green nesting material has a function in mate attraction in the European Starling. Animal Behaviour 67(3): 539548. 4 .

Brown CR and Brown MB (1991). Selection of high-quality host nests by parasitic cliff swallows. Animal Behavior 41: 457-465

CLARK, L. \& J.R. MASON (1985): Use of nest material as insecticidal anti-pathogenic agents by the European Starling. Oecologia 67: 169-176.

Collection of Images, Videos, Taxonomic description of birds in the World. www.internetbirds.com, November 2015.

D FAUTH, P.T., D.G. KREMENTZ \& J.E. HINES (1991): Ectoparasitism and the role of green nesting material in the European Starling. Oecologia 88:
22-29 EWAR, D. (1909): The nesting habit of the Baya. J. Bombay Nat. Hist. Soc. 19: 627-634.

DAVIS, T.A. (1973): Mud and dung plastering in Baya nest. J. Bombay Nat. Hist. Soc. 70(1): 57-71.

Duckworth, R. A. (2008). The role of behavior in evolution: A search for mechanism. Evolutionary Ecology, 23(4), 513-531

HC. Chaya and H. Channaveerappa (2012). Effect of Red Ants invasion on the Nesting and Brood of Indian Cliff Swallows. Int. J. Adv. Pharma., Bio Chem. Vol. 1 (4),

James at.el. 2012: Ground-foraging techniques of Welcome Swallows Hirundo neoxena, including an instance of kleptoparasitism: Australian Field Ornithology 2012, 29, 160-165

Kilgore D L Jr and K L Knudsen, 1977, Analysis of Material in Cliff \& Baron Swallow nests: Relationship between mud selection and nest architecture,TheWilson bulletin89. No. 4:562571

Lapiedra, O., Sol, D., Carranza, S., \& Beaulieu, J. M. (2013). Behavioral changes and the adaptive diversification of pigeons and doves. Proceedings of the Royal Society of London. Series B: Biological Sciences, 280(1755), 20122893

MATHEW, D.N. (1972): The ecology of the baya in Rajampet, Cuddapah district, Andhra Pradesh. J. Bombay Nat. Hist. Soc. 69(1): 188-191.

Møller AP (1992). Sexual selection in the monogamous barn swallow (Hirundo rustica). The mechanisms of sexual selection. Journal of Evolutionary Biology 5: 603-624.

P. Balkrishnan (2010) : BREEDING BIOLOGY OF THE HILL SWALLOW HIRUNDO DOMICOLA IN WESTERN GHATS, INDIA; Journal of the Bombay Natural History Society, 107(2), MayAug 2010 109-115

Pande, Satish 2001. (SP, SNP): The clandestine trade of nests of the Edible-nest Swiftlets at Vengurla Rocks. Pitta. (May 2001) 121: 1.

Pande, Satish 2005. (SP, SNP):The First Ocean Bird Survey and Coastal Bird Survey in the Arabian Sea and the west coast of India fron1 MUIllbai to New Mangalore. Pp.1-36. (Unpubl. Report with colour 
photographs, subInitted to the Director General, Indian Coast Guard)

Pande, Satish 2006. (SP, SNP): The Second Pelagic Bird Survey In the Arabian Sea To and From New Mangapore to Lakshadweep Islands: 1-59. (Unpubl. Report with colour photographs, submitted to the Director General, Indian Coast Guard).

Praveen at.el. (2015) : Bird diversity of protected areas in the Munnar Hills, Kerala, India; Indian BIRDS 10

$1-12$.

https://www.researchgate.net/publication/275957 $\underline{332}$

Raslllussen, P. C. and Anderton, J. C. (2005) Birds o.f South Asia : The Ripley Guide. Smithsonian Institution \& Lynx Edicion. Washington D. C. and Barcelona. Vol. $1: 1-378$ and Vol. 2 : 1-683

Salim Ali (1941): The Book of Indian Birds Page 164, 165

Sharath V.G1, Devi Prasad A.G (2019): Avifaunal Diversity in Western Ghats Regions of Shimoga and Chikmagalur Districts, Karnataka, India, IOSR Journal of Environmental Science, Toxicology and Food Technology (IOSR-JESTFT) e-ISSN: 23192402,p- ISSN: 2319-2399.Volume 13, Issue 3 Ser. II (March. 2019), PP 71-89 www.iosrjournals.org.

SHARMA, S.K. (1991): Plant life and weaver birds (with special reference to eastern Rajasthan). Ph.D. Thesis. University of Rajasthan, Rajasthan

Shivaji.at.el ( 2014) : Mud nests of Wire-tailed Swallow (Hirundo filifera): Biomarkers of Ecological niche in Godavari river ecosystem, Nanded, Maharashtra State, Advances in Bioresearch Adv. Biores., Vol 7 (2) March 2016: 170-175 (C2015 Society of Education, India Print ISSN 0976-4585; Online ISSN 2277-1573 Journal's URL:http://www.soeagra.com/abr.html CODEN: ABRDC3 ICV Value 8.21 [2014].

Sunjoy Mongaat (2009 to 2011 -Two phases of Project): MMR BIODIVERSITY PROJECT -MMR Biodiversity Project - sponsored by MMR-EIS (page 64)

Swati at.el. (2012): Diversity of birds in some ecological niches of Western Ghats in Maharashtra (India). Research \& Reviews in BioSciences ; ISSN : 0974 - 7532RRBS, 6(9), 2012 [231-239]

Turner, A. K. (2004). Family Hirundidae Swallows and martins), Pp. 602-685. In: del Hoyo, J., A. Eliott $\&$ D. A. Christic (Eds): Handbook of the Birds of the World. Vol. 9. Lynx Editions, Barcelona.

TURNER, A.K. (2004): Family Hirundinidae (swallows and martins). Pp. 602-685. In: del Hoyo, J., A. Eliott \& D.A. Christie (Eds): Handbook of the Birds of the World. Vol. 9. Lynx Editions, Barcelona.

Turner, Angela (2004). "Family Hirundinidae (Swallows and Martins)". In Josep del Hoyo; Andrew Elliott; David A. Christie (eds.). Handbook of the Birds of the World. Volume 9. Lynx Edicions. pp. 602638. ISBN 978-84-87334-69-6.

Nest of Indian Cliff Swallow Hirundo fluvicola Blyth 1885

Gourd shaped.

Broken nest partly

Broken nest partly

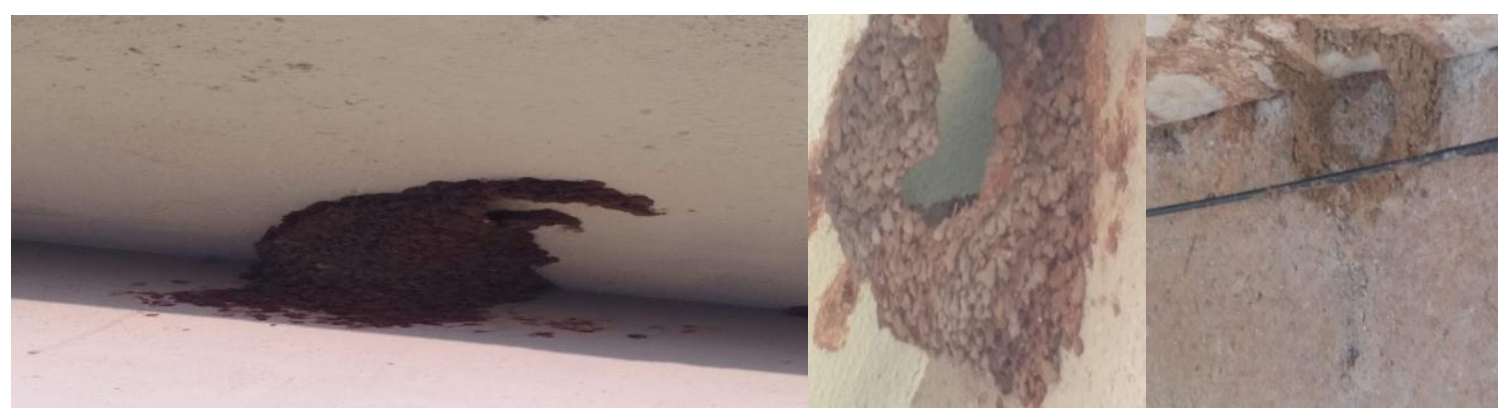

Figure 1

Figure 2

Figur 
Nests of Wire-tailed Swallow Hirundo filifera Stephans, 1825 on underside of terrace.

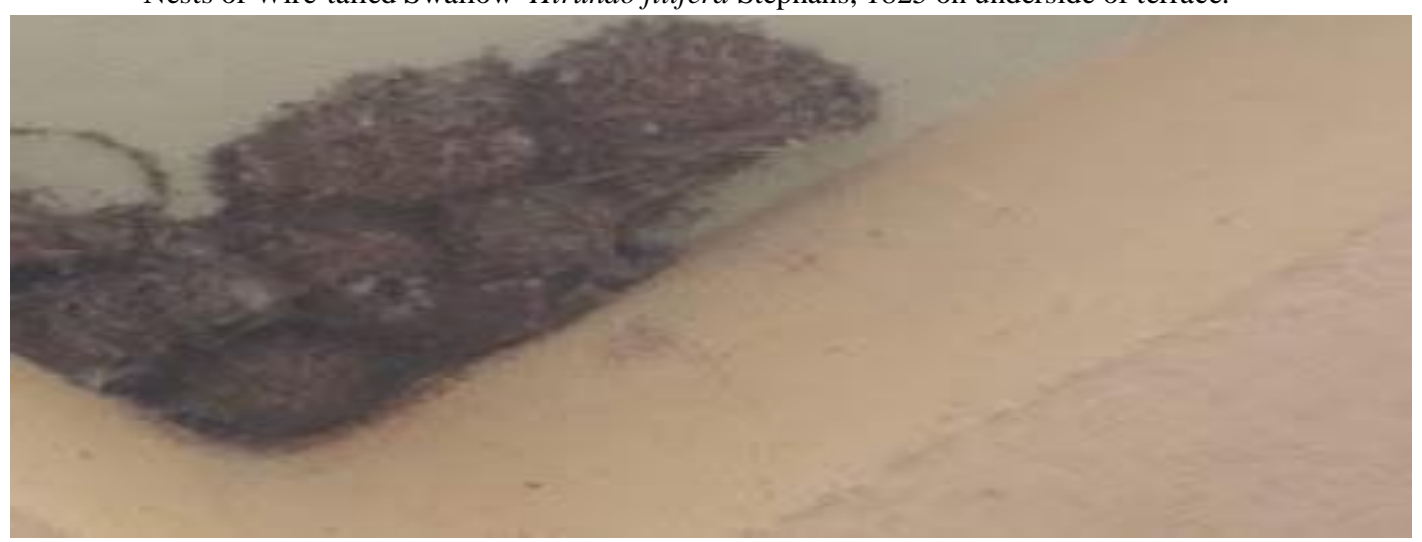

Figure 4

Table 1: showing details of one or few observations at every site visited randomly.

\begin{tabular}{|c|c|c|c|c|c|c|c|}
\hline $\begin{array}{l}\text { Site } \\
\text { No. }\end{array}$ & Location of sites & $\begin{array}{l}\text { Nests } \quad \begin{array}{r}\text { found } \\
\text { in/under man }\end{array} \\
\text { made structures } \\
\text { / Natural habitat }\end{array}$ & $\begin{array}{l}\text { Water } \\
\text { bodies } \\
\text { present } \\
\text { with in } \\
100 \text { Mts. } \\
\text { Area }\end{array}$ & $\begin{array}{l}\text { No. of } \\
\text { nests } \\
\text { found }\end{array}$ & $\begin{array}{l}\text { No.of } \\
\text { roun } \\
\text { ds to } \\
\text { build } \\
\text { a } \\
\text { nest }\end{array}$ & $\begin{array}{l}\text { No. of visits } \\
\text { after hatching } \\
\text { of eggs till } \\
\text { juveniles are } \\
\text { grown } \\
\text { swallows by } \\
\text { in one hour }\end{array}$ & $\begin{array}{l}\text { Clutch } \\
\text { size }\end{array}$ \\
\hline \multirow[t]{2}{*}{1} & Pen (Swallows) & Bridges / buildings & Yes/No & 200 & 1500 & 23 & 3-4 eggs \\
\hline & $\begin{array}{l}\text { Murud } \\
\text { (Swallows/Swifts) }\end{array}$ & $\begin{array}{l}\text { Tunnels, culverts, } \\
\text { buildings, under } \\
\text { caves or ceilings }\end{array}$ & Yes/No & $500 / 34$ & 1450 & 43 & $2-3$ eggs \\
\hline \multirow[t]{2}{*}{2} & Uran (Swallows) & Caves, buildings, & Yes/no & 35 & 1600 & 54 & 3-4eggs \\
\hline & Panvel (Swallows) & Buildings & No/Yes & 545 & 1765 & 65 & 2 eggs \\
\hline \multirow[t]{2}{*}{3} & Poladpur(Swallows) & Tunnels,Buildings & No/Yes & 375 & 1674 & 37 & $2-3$ eggs \\
\hline & $\begin{array}{l}\text { Mahad } \\
\text { (Swallows/swifts) }\end{array}$ & $\begin{array}{l}\text { Mounds, } \\
\text { buildings, bridges }\end{array}$ & Yes/no & $1234 / 28$ & 1800 & 61 & 3-4 eggs \\
\hline \multirow[t]{2}{*}{4} & $\begin{array}{l}\text { Tala } \\
\text { (swallows) }\end{array}$ & $\begin{array}{l}\text { Buildings, bridges } \\
\text { at various places }\end{array}$ & Yes/No & 200 & 1678 & 32 & 3 eggs \\
\hline & $\begin{array}{l}\text { Roha } \\
\text { (swallows) }\end{array}$ & $\begin{array}{l}\text { Under } \begin{array}{l}\text { Water } \\
\text { tanks, buildings }\end{array}\end{array}$ & Yes/No & 354 & 1456 & 65 & 4 eggs \\
\hline
\end{tabular}

Note: where water bodies are not present there also nests were sighted because swallows used wet soil during rainy season for construction of nests and sometimes other sources wetting soils were also used by birds to establish their nests.

Table no.2 showing details of other species available with references in characterstics.

\begin{tabular}{|c|c|c|c|c|}
\hline $\begin{array}{l}\text { Sr. } \\
\text { nos }\end{array}$ & Species Name & Characters & Behaviour & Classification \\
\hline 1 & $\begin{array}{l}\text { Indian } \\
\text { Swallow } \\
\text { Hirundo } \\
\text { fluvicola } \\
1885\end{array}$ & $\begin{array}{l}\text { A small Swallow with a very } \\
\text { slightly forked tail. Above glossy } \\
\text { steel blue brown rump. Below } \\
\text { fulvous white, profusely streaked } \\
\text { with blackish on sides of head, } \\
\text { Chin, throat and breast, } \\
\text { Sexes:Alike } \\
\text { Resident or Partly migratory } \\
\text { Colonial nest. }\end{array}$ & $\begin{array}{l}\text { Native (breeder, year- } \\
\text { round resident or } \\
\text { winter visitor) } \\
\text { The architecture of } \\
\text { the nest resembles } \\
\text { the inverted dome or } \\
\text { gourd. }\end{array}$ & $\begin{array}{l}\text { Kingdom:Animalia } \\
\text { Phylum :Chordata } \\
\text { Class:Aves } \\
\text { Order:Passireformes } \\
\text { Family:Hirundnidae } \\
\text { S.Fam:Hirudninae } \\
\text { Genus:Hirundo } \\
\text { Species: Hirundo } \\
\text { fluvicola Blyth } 1885\end{array}$ \\
\hline 2 & $\begin{array}{l}\text { Hill Swallow } \\
\text { Hirundo } \\
\text { domicola }\end{array}$ & $\begin{array}{l}\text { This species is a small swallow at } \\
13 \mathrm{~cm} \text { ( } 5.1 \mathrm{in}) . \text { It has a blue back } \\
\text { with browner wings and tail, a red } \\
\text { face and throat, and dusky } \\
\text { underparts. }\end{array}$ & $\begin{array}{l}\text { Foraging behavior } \\
\text { seems to be at peak } \\
\text { during breeding } \\
\text { season on during Feb } \\
\text { /Nov in different } \\
\text { areas. }\end{array}$ & $\begin{array}{l}\text { Kingdom:Animalia } \\
\text { Phylum :Chordata } \\
\text { Class:Aves } \\
\text { Order:Passireformes } \\
\text { Family:Hirundnidae } \\
\text { S.Fam:Hirudninae }\end{array}$ \\
\hline
\end{tabular}




\begin{tabular}{|c|c|c|c|c|}
\hline & & & $\begin{array}{l}\text { Cup shaped nests } \\
\text { Tunnel/culver nest }\end{array}$ & $\begin{array}{l}\text { Genus: Hirundo } \\
\text { Species: Hirundo } \\
\text { domicola }\end{array}$ \\
\hline 3 & $\begin{array}{l}\text { Wire-tailed } \\
\text { Swallow } \\
\text { Hirundo } \\
\text { filifera } \\
\text { Stephans, } \\
1825\end{array}$ & $\begin{array}{l}\text { The nest is similar to that of the } \\
\text { Crag-Martin, but the mud is } \\
\text { reinforced with grass and straw. It } \\
\text { is fixed in the corner of a } \\
\text { verandah near the ceiling, under } \\
\text { caves or against rafters in } \\
\text { buildings, both inhabited and } \\
\text { disused. Several birds may be } \\
\text { seen loosely together skimming } \\
\text { over the surface of a jheel or } \\
\text { village tank, or hawking insects a } \\
\text { few feet above it or over ploughed } \\
\text { fields around its margin. The nest } \\
\text { does not diller from that of the } \\
\text { Crag-Martin. It is attached under } \\
\text { arches of bridges and culverts, to } \\
\text { cliffs flanking streams, and } \\
\text { frequently to rafters in the } \\
\text { verandahs of bungalows. The nest } \\
\text { is usually solitary, but } \\
\text { occasionally several are built close } \\
\text { together.. (Salim Ali). }\end{array}$ & $\begin{array}{l}\text { Foraging behavior } \\
\text { continuously with a } \\
\text { little break in search } \\
\text { of food or to monitor } \\
\text { nests }\end{array}$ & $\begin{array}{l}\text { Kingdom:Animalia } \\
\text { Phylum : Chordata } \\
\text { Class:Aves } \\
\text { Order:Passireformes } \\
\text { Family:Hirundnidae } \\
\text { S.Fam:Hirudninae } \\
\text { Genus:Hirundo } \\
\text { Hirundo filifera } \\
\text { Stephans, } 1825\end{array}$ \\
\hline 4 & $\begin{array}{l}\text { Common/ } \\
\text { Barn Swallow } \\
\text { Hirundo } \\
\text { rustica }\end{array}$ & $\begin{array}{l}\text { It has steel blue outer or upper } \\
\text { parts and a rufous forehead, chin } \\
\text { and throat, which are separated } \\
\text { from the off-white underparts by a } \\
\text { broad dark blue breast band. The } \\
\text { outer tail feathers are elongated, } \\
\text { giving the distinctive deeply } \\
\text { forked "swallow tail". There is a } \\
\text { line of white spots across the } \\
\text { outer end of the upper tail. }\end{array}$ & $\begin{array}{l}\text { In winter, the barn } \\
\text { swallow is } \\
\text { cosmopolitan in its } \\
\text { choice of habitat, } \\
\text { avoiding only dense } \\
\text { forests and deserts. }\end{array}$ & $\begin{array}{l}\text { Kingdom:Animalia } \\
\text { Phylum :Chordata } \\
\text { Class:Aves } \\
\text { Order:Passireformes } \\
\text { Family:Hirundnidae } \\
\text { S.Fam:Hirudninae } \\
\text { Genus:Hirundo } \\
\text { Species: Hirundo } \\
\text { rustica }\end{array}$ \\
\hline 5 & $\begin{array}{l}\text { House swift } \\
\text { Apus affinus }\end{array}$ & $\begin{array}{l}\text { A small smoky black swallow-like } \\
\text { bird with conspicuous white } \\
\text { rump, white throat,short square } \\
\text { tail and a long narrow sickle } \\
\text { shaped wings. Seen in scattered } \\
\text { rabbles wandering over towns and } \\
\text { villages, Sexes alike, It is a } \\
\text { resident and common bird. Local } \\
\text { migration in some areas. It is dark } \\
\text { brown. Bill black. Legs and feet } \\
\text { dark purplish black. } \\
\text {.Breeding Nov to Feb. }\end{array}$ & $\begin{array}{l}\text { It is capable of flying } \\
\text { long distances }\end{array}$ & $\begin{array}{l}\text { Kingdom:Animalia } \\
\text { Phylum :Chordata } \\
\text { Class: Aves } \\
\text { Order: Apodiformes } \\
\text { Sub -Order: Apodi } \\
\text { Family: Apodidae, } \\
\text { Genus: Apus } \\
\text { Species: Apus affinus }\end{array}$ \\
\hline 6 & $\begin{array}{l}\text { Swift Alpine } \\
\text { Tachymarpitis } \\
\text { melba }\end{array}$ & $\begin{array}{l}\text { A large sooty brown swift with } \\
\text { white underparts and a brown } \\
\text { pectoral band across breast, } \\
\text { Sexes alike. Body plumage } \\
\text { brownish. Wing feathers } \\
\text { (especially secondaries) more } \\
\text { greyish brown. Incubation period } \\
18-19 \text { days, }\end{array}$ & & $\begin{array}{l}\text { Kingdom:Animalia } \\
\text { Phylum : Chordata } \\
\text { Class: Aves } \\
\text { Order: Apodiformes } \\
\text { Family: Apodidae, } \\
\text { S.Fam: Apodinae } \\
\text { Genus: Tachymarptis } \\
\text { Species: } \\
\text { Tachymarpitis melba }\end{array}$ \\
\hline
\end{tabular}


Table 3: Number of foraging records of 3 bird species without considering height.

\begin{tabular}{|c|c|c|c|}
\hline Sr,Nos & Name of species & $\begin{array}{l}\text { Foraging every one } \\
\text { hours with break in } \\
\text { between in a single day } \\
\text { of season }\end{array}$ & Ground foraging \\
\hline 1 & $\begin{array}{l}\text { Indian Cliff Swallow } \\
\text { Hirundo fluvicola Blyth } 1885\end{array}$ & $45,21,61,52,46,34,43$ & Twice seen on ground \\
\hline 2 & $\begin{array}{l}\text { Hill Swallow } \\
\text { Hirundo domicola }\end{array}$ & $34,45,56,21,33,45.51$ & Never \\
\hline 3 & $\begin{array}{l}\text { Wire-tailed Swallow } \\
\text { Hirundo filifera } \\
\text { Stephans, } 1825 \\
\end{array}$ & $66,54,23,53,46,61,45$ & Never \\
\hline 4 & $\begin{array}{l}\text { Common/ Barn Swallow } \\
\text { Hirundo rustica }\end{array}$ & $23,55,45,23,12,33,45$ & Never \\
\hline 5 & $\begin{array}{l}\text { House swift } \\
\text { Apus affinus }\end{array}$ & $70,65,63,56,62,66,43$ & Never \\
\hline 6 & $\begin{array}{l}\text { Swift Alpine } \\
\text { Tachymarpitis melba }\end{array}$ & $71,65,55,36,54,67,44$ & Never \\
\hline
\end{tabular}

Table no.4; Showing comparison of different species with species under study.

\begin{tabular}{|c|c|c|c|c|}
\hline $\begin{array}{l}\text { Sr.No } \\
\text { s }\end{array}$ & Species Name & Area found & Characterstics & Author \\
\hline 1 & Hill Swallow Hirundo domicola & $\begin{array}{l}\text { Silent } \\
\text { Valley } \\
\text { National } \\
\text { Park and } \\
\text { Muthikkula } \\
\text { m Reserve } \\
\text { Forests, } \\
\text { Western } \\
\text { Ghats, } \\
\text { India. }\end{array}$ & $\begin{array}{l}\text { All the breeding sites were located } \\
\text { within an elevation range of } 800 \text { to } \\
1,200 \mathrm{~m} \text { above msl } \\
\text { All the nests were cup-shaped } \\
\text { (nest diameter: } 11.43 \pm 0.72 \mathrm{~cm} \text {, } \\
\text { cup diameter: } 8.59 \pm 0.71 \mathrm{~cm} \text {, } \\
\text { outer nest depth: } 7.84 \pm 0.71 \mathrm{~cm} \text {, } \\
\text { cup depth: } 5.2 \pm 0.72 \mathrm{~cm} \text {, nest } \\
\text { thickness: } 1.42 \pm 0.32 \mathrm{~cm} \text { ) } \\
\text { All the nest sites were in the } \\
\text { vicinity of water } \\
\text { No. of eggs } 53 \text { in Silent Valley } \\
\text { No. of eggs } 35 \text { in Muthikkulam }\end{array}$ & $\begin{array}{l}\text { P. } \\
\text { Balakrish } \\
\text { nan }\end{array}$ \\
\hline 2 & $\begin{array}{l}\text { Wire-tailed Swallow (Hirundo } \\
\text { filifera): Stephans, 1826) }\end{array}$ & $\begin{array}{l}\text { Godavari } \\
\text { river } \\
\text { ecosystem, } \\
\text { Nanded }\end{array}$ & $\begin{array}{l}556 \text { mud nests in Godavari river } \\
\text { basin, Nanded Stephans, 1826). } \\
\text { About 1000-1400 mud pellets } \\
\text { were used to construct single nest. } \\
\text { Details of time required to } \\
\text { construct various parts of mud } \\
\text { nest are variable from few hours to } \\
\text { few days. } \\
\text { The nesting material mainly } \\
\text { composed of sand, silt and clay; } \\
\text { also consists of crushed parts of } \\
\text { bivalve shells, feathers etc. }\end{array}$ & $\begin{array}{l}\text { Chavan } \\
\text { Shivaji } \\
\text { at.el.(2014 } \\
\text { ) }\end{array}$ \\
\hline 3 & $\begin{array}{l}\text { Common/ Barn Swallow } \\
\text { Hirundo rustica }\end{array}$ & $\begin{array}{l}\text { Western } \\
\text { Ghats } \\
\text { Regions of } \\
\text { Shimoga } \\
\text { and }\end{array}$ & $\begin{array}{l}\text { Order: Hirundidinidae } \\
\text { Occurances:Common } \\
\text { Migratory Status:Resident } \\
\text { Habitat: Wet lands } \\
\text { Food: Insectivorous } \\
\text { Sexual Morphology: Alike }\end{array}$ & $\begin{array}{l}\text { Sharath } \\
\text { at.el.(2019 } \\
\text { ). }\end{array}$ \\
\hline
\end{tabular}




\begin{tabular}{|c|c|c|c|c|}
\hline & & $\begin{array}{l}\text { Chikmagal } \\
\text { ur } \\
\text { Districts, } \\
\text { Karnataka, } \\
\text { India }\end{array}$ & $\begin{array}{l}\text { Nesting Period:April to July } \\
\text { Status:Least Common } \\
\text { Trends of Population: Decreasing }\end{array}$ & \\
\hline 4 & $\begin{array}{l}\text { Wire tailed Swallow } \\
\text { Hirundo smithii }\end{array}$ & $\begin{array}{l}\text { Western } \\
\text { Ghats } \\
\text { Regions of } \\
\text { Shimoga } \\
\text { and } \\
\text { Chikmagal } \\
\text { ur } \\
\text { Districts, } \\
\text { Karnataka, } \\
\text { India }\end{array}$ & $\begin{array}{l}\text { Order: Hirundidinidae } \\
\text { Occurances:Common } \\
\text { Migratory Status:Resident } \\
\text { Habitat: Wet lands } \\
\text { Food: Insectivorous } \\
\text { Sexual Morphology: Alike } \\
\text { Nesting Period: All Year } \\
\text { Status: Least Common } \\
\text { Trends of Population: Increasing }\end{array}$ & $\begin{array}{l}\text { Sharath } \\
\text { at.el.(2019 } \\
\text { ). }\end{array}$ \\
\hline 5 & $\begin{array}{l}\text { Common Swallow } \\
\text { Hirundo rustica }\end{array}$ & $\begin{array}{l}\text { Near } \\
\text { Kotagiri, } \\
\text { Coonoor } \\
\text { and Ooty } \\
\text { town. } \\
\text { Davison } \\
(1883) \\
\text { recorded it } \\
\text { as common } \\
\text { in the } \\
\text { Nilgiris }\end{array}$ & $\begin{array}{l}\text { Common winter visitor, } \\
\text { Betts (1930) records its arrival in } \\
\text { the Nilgiris as early as October }\end{array}$ & \\
\hline 6 & $\begin{array}{l}\text { House } \\
\text { Swallow } \\
\text { Hirundo tahitica }\end{array}$ & $\begin{array}{l}- \\
\text { Upper } \\
\text { Nilgiris }\end{array}$ & $\begin{array}{l}\text { House swallow } \\
\text { Hirundo tahitica Common } \\
\text { resident, widespread, seen } \\
\text { practically throughout the. Several } \\
\text { nests recorded at different } \\
\text { locations in March and April. Two } \\
\text { nests seen in April } 2002 \text { in our } \\
\text { garage were reoccupied in } 2003 \\
\text { with little modification. }\end{array}$ & $\begin{array}{l}\text { Ashfaq } \\
\text { Ahmed } \\
\text { Zarri and } \\
\text { Asad R. } \\
\text { Rahmani }\end{array}$ \\
\hline 7 & $\begin{array}{l}\text { Red Rumped swallow } \\
\text { Hirundo daurica }\end{array}$ & $\begin{array}{l}\text { Bangitappa } \\
1 \text { Valley }\end{array}$ & $\begin{array}{l}\text { Rare passage migrant to the study } \\
\text { area, a flock of nearly } 100 \\
\text { individuals seen on } 2 \text { November } \\
2003 \text {, } \\
\text { Flock making a nasal "queenk" } \\
\text { every now and then. }\end{array}$ & $\begin{array}{l}\text { Ashfaq } \\
\text { Ahmed } \\
\text { Zarri and } \\
\text { Asad R. } \\
\text { Rahmani }\end{array}$ \\
\hline 8 & $\begin{array}{l}\text { House swift } \\
\text { Apus affinus }\end{array}$ & $\begin{array}{l}\text { Dasve and } \\
\text { Warasgaon } \\
\text { reservoirs, } \\
\text { Western } \\
\text { Ghats in } \\
\text { Maharashtr } \\
\text { a }\end{array}$ & ----------------- & $\begin{array}{l}\text { Swati } \\
\text { at.el.(2012 } \\
\text { ). }\end{array}$ \\
\hline 9 & $\begin{array}{l}\text { Dusky Crag Martin } \\
\text { Hirundo concolor } \\
\text { Wire-Tailed Swallow } \\
\text { Hirundo smithii } \\
\text { Barn Swallow } \\
\text { Hirundo rustica } \\
\text { Red Rumped Swallow } \\
\text { Hirundo daurica }\end{array}$ & Nigade & $\begin{array}{l}\text { Rare } \\
\text { Rare } \\
\text { Migratory } \\
\text { Rare }\end{array}$ & $\begin{array}{l}\text { Kuldeep } \\
\text { at.el.( } \\
\text { 2013) }\end{array}$ \\
\hline
\end{tabular}




\begin{tabular}{|c|c|c|c|c|}
\hline 10 & Collocalia unicolor & $\begin{array}{l}\text { Vengurla } \\
\text { Rocks } \\
\text { Archipelago }\end{array}$ & $\begin{array}{l}\text { build pure and white nests which } \\
\text { have a which have a commercial } \\
\text { culinary value. } \\
\text { Half-Cup Shaped nest. } \\
\text { Blackish brown and rump } \\
\text { concolorus } \\
\text { Nesting: March to June } \\
\text { Nest:Whitish, translucent to } \\
\text { opaque with some mixture of } \\
\text { extraneous matter } \\
\text { Legs and feet purplish black. }\end{array}$ & $\begin{array}{l}\text { Anil } \\
\text { Mahabal } \\
\text { at.el.(2007 } \\
\text { ) }\end{array}$ \\
\hline 11 & Collocalia fuciphaga & $\begin{array}{l}\text { Vengurla } \\
\text { Rocks } \\
\text { Archipelao }\end{array}$ & $\begin{array}{l}\text { Build pure and white nests which } \\
\text { have a which have a commercial } \\
\text { culinary value. } \\
\text { More or less Half -Cup Shaped } \\
\text { nest. Legs and browinish } \\
\text { Nest:Whitish, translucent to } \\
\text { opaque with no mixture of } \\
\text { extraneous matter. }\end{array}$ & $\begin{array}{l}\text { Anil } \\
\text { Mahabal } \\
\text { at.el.(2007 } \\
\text { ) }\end{array}$ \\
\hline 12 & $\begin{array}{l}\text { Wire tailed Swallow Hirundo } \\
\text { smithii, } \\
\text { Swift Alpine Tachymarpitis } \\
\text { melba, Red Rumped Swallow } \\
\text { Hirundo daurica }\end{array}$ & $\begin{array}{l}\text { Tamhini } \\
\text { Ghat }\end{array}$ & e & $\begin{array}{l}\text { Anand } \\
\text { at.el } \\
(2007)\end{array}$ \\
\hline 13 & $\begin{array}{l}\text { Sand Martin Riparia riparia, } \\
\text { Dusky Crag Martin } \\
\text { Ptyonoprogne concolor, } \\
\text { Eurasian Crag Martin } \\
\text { Ptyonoprogne rupestris, } \\
\text { Streak-Throated Swallow } \\
\text { Hirundo fluvicola Nahar ababil } \\
\text {, Barn Swallow Hirundo } \\
\text { rustica Masjid-ababil, } \\
\text { Red-Rumped Swallow } \\
\text { Hirundo daurica Masjid- } \\
\text { ababil , } \\
\text { Wire-Tailed Swallow } \\
\text { Hirundo smithii, }\end{array}$ & ------------- & --------- & $\begin{array}{l}\text { Sunjoy } \\
\text { Mongaat } \\
\text { (2009 to } \\
2011 \text {-Two } \\
\text { phases of } \\
\text { Project): }\end{array}$ \\
\hline 14 & $\begin{array}{l}\text { Asian Palm Swift Cypsiurus } \\
\text { balasiensis, } \\
\text { Alpine Swift Tachymarptis } \\
\text { melba, } \\
\text { House Swift } \\
\text { Apus affinis, } \\
\text { Crested Treeswift } \\
\text { Hemiprocne coronata, } \\
\text { Barn Swallow } \\
\text { H. tahitica, } \\
\text { Wire-tailed Swallow } \\
\text { H. smithii, } \\
\text { Red-rumped Swallow } \\
\text { H. daurica, Streak-throated } \\
\text { Swallow } \\
\text { H. fluvicola }\end{array}$ & $\begin{array}{l}\text { Sharavathy } \\
\text { landscape, } \\
\text { Karnataka. }\end{array}$ & ---- & $\begin{array}{l}\text { Barve } \\
\text { at.el } \\
(2011) \text { : }\end{array}$ \\
\hline 14 & $\begin{array}{l}\text { Wire-tailed Swallow } \\
\text { Hirundo smithii }\end{array}$ & $\begin{array}{l}\text { Navi } \\
\text { Mumbai }\end{array}$ & occasional & $\begin{array}{l}\text { Asad } \\
\text { at.el.(2013 } \\
\text { ) }\end{array}$ \\
\hline 16 & $\begin{array}{l}\text { Barn Swallow } \\
\text { Hirundo rustica }\end{array}$ & $\begin{array}{l}\text { Navi } \\
\text { Mumbai }\end{array}$ & & $\begin{array}{l}\text { Asad R. } \\
\text { Rahmani } \\
\text { at.el.(2013 } \\
\text { ): }\end{array}$ \\
\hline
\end{tabular}




\begin{tabular}{|c|c|c|c|c|}
\hline 17 & $\begin{array}{l}\text { Dusky Crag-Martin } \\
\text { Ptyonoprogne concolor } \\
\text { R Hirundinidae } \\
\text { Barn Swallow } \\
\text { Hirundo rustica } \\
\text { Red-rumped Swallow } \\
\text { Cecropis daurica, } \\
\text { Wire-tailed } \\
\text { Swallow } \\
\text { Hirundo smithii }\end{array}$ & ---------- & -------------- & $\begin{array}{l}\text { Anish } \\
\text { Pardeshi } \\
\text { at.el. } \\
(2017)\end{array}$ \\
\hline 18 & $\begin{array}{l}\text { Hill Swallow } \\
\text { Hirundo domicola, Eurasian } \\
\text { Crag Martin Ptyonoprogne } \\
\text { rupestris, } \\
\text { Dusky Crag Martin } \\
\text { P. concolor, } \\
\text { Common House Martin } \\
\text { Delichon urbicum i }\end{array}$ & $\begin{array}{l}\text { Munnar } \\
\text { Hills, } \\
\text { Kerala. }\end{array}$ & ------------------------- & $\begin{array}{l}\text { Praveen } \\
\text { at.el. } \\
(2015)\end{array}$ \\
\hline
\end{tabular}

